\title{
Imprisoning the open air: Preventive policing as community detention in northwestern China*
}

Darren Byler

\begin{abstract}
S ometime in May 2017, an ethnic Kazakh woman was detained in Ürümqi, the capital of the Xinjiang Uyghur Autonomous Region. Perhaps this woman, a Chinese citizen, had travelled to Kazakhstan in the past or had relatives there. Perhaps she had become part of a Quran study group on WeChat. It may not even be clear to her what 'micro-clue' of her potential 'extremism' resulted in her detention. In any case, once she was in custody, a scan of her smartphone revealed that she had been in contact with a Uyghur woman in Kazakhstan. Eager to please her interrogators, whose priority was to capture 'returning terrorists', she placed a call to the woman in Almaty. She told this woman, Gulbahar Jelilova, that her mother, Gulbahar's partner in a shuttle trade business, was in hospital so Gulbahar would need to travel across the border to Ürümqi to pick up the products she had ordered for export to Kazakhstan. Gulbahar was suspicious at first, because she had heard about the mass detention of Turkic Muslims that had begun earlier that year, but because she knew her partner had a heart condition, she thought perhaps the story of her illness was true. Since she was a Kazakhstani citizen born in Kazakhstan, she thought she had nothing to worry about despite her Uyghur ethnicity. The morning after she arrived in Ürümqi, she found out how wrong she was. She said:
\end{abstract}

At 8 am, the police knocked on my door. They showed me their badges and then said they had a few questions to ask me. I thought they really would just ask a few questions, so I went along with them [without any attempt to resist]. As soon as we arrived at the police station, they checked my phone. When they couldn't find

"This essay was originally published in the Made in China Journal (vol. 4, no. 3, 2019), doi.org/I 0.22459/MIC.04.03.2019.13. The article has been updated for inclusion in this volume. 
anything, they showed me the picture of my friend and asked if I knew her. Then I realised they had already detained her. They had found my phone number in her cell phone and pressured her daughter to call me. Then they accused me of wiring 17,000 yuan to Turkey. I said, why would I do that? They said: 'Take your time, think it over.'

As it turned out, Gulbahar was given plenty of time to think about this. For the next year, three months, and 10 days, she was held in a series of detention centres in Ürümqi. The conditions in these holding centres, where detainees were investigated for potential connections to terrorism, were horrific. She and the more than 30 other Turkic Muslim women who shared her 14-square-metre cell were forced to take turns sleeping because there was not enough room for everyone to stretch out. The lights were never turned off. Their movements and speech were recorded by cameras and microphones.

Gulbahar, who spoke no Chinese, learned to say 'thank you' (谢谢) and 'here' (到) and to sing the Chinese national anthem, The March of the Volunteers. Every day she watched political speeches on TV monitors mounted high on the wall. This was the 'reeducation' (再教育) component of her detention.

Her interrogators showed her a brand-new Chinese ID card and made her memorise her new 18-digit citizenship number. They told her she was not Gulbahar Jelilova, she was a Chinese citizen now, and she should confess her crimes.

Gulbahar had been caught up in the reeducation system that explicitly targets Turkic Muslims. She was one of as many as 1.5 million people who had exhibited the 'early warning' (预警) signs of terrorism. This preventive policing system was built on modes of counterinsurgency that emerged from the United States, Israel, and Europe, but was adapted to 'Chinese characteristics' (中国特色) that came from China's Maoist past. Together, these modes and technologies have produced a coercive internment camp system that is implemented by an army of more than one million non-Muslim civil servants and police (Byler 2018; see also Salimjan's Chapter 7 in this volume). The project is supported by a

I This quote is an extract from a video interview conducted by the Uyghur-language TV channel in Turkey called Pidaiylar Ekrani (2018). The interview was translated by the author and an anonymous viewer.The interview is available from: www.youtube.com/watch?v=VILgyCn-gSO. 
comprehensive, AI-assisted biometric and digital surveillance system. The scale of detentions and the use of technology make the Chinese counterinsurgency unprecedented. It is the American war in Iraq without organised, weaponised insurgents and without mass killing; a Countering Violent Extremism (CVE) program with purpose-built internment camps and state-run residential schools. It has adapted counterinsurgency to produce a new form of contemporary settler colonialism. The political and material structure of this colonialism partition Uyghur and Kazakh communities, removing and dispossessing them of their land and their remaining social institutions: their language, faith, family, and cultural traditions. The technology-assisted forms of policing that characterise this system produce a racialised relationship of state and settler domination over their lives.

\section{A global shift in counterinsurgency}

The experiences of Gulbahar Jelilova and others in her social network are indicative of a broader shift in policing and detention in northwestern China and counterinsurgency around the world. As David Brophy has shown in his chapter in this volume, since 2014, Chinese authorities have adopted forms of Islamophobia and counterinsurgent militarism that are similar to those of the post-9/11 United States and other nations. As in the US-led occupation of Iraq and Afghanistan in the mid-2000s, Chinese police have transformed Xinjiang into a space of exception-a counterinsurgent war zone where active militants are thought to be hiding among the 'neutral population' (Harcourt 2018). In the American case, the only way to detect and uproot these terrorists-in-hiding was through full-spectrum intelligence encompassing all inhabitants in the war theatre. Once knowledge dominance was achieved, the networks of the insurgency could be traced and fractured through processes of removal and isolation. The final step in counterinsurgency implementation was winning 'the hearts and minds' of a targeted population through humanitarian aid, infrastructure building, and job training. This, it was thought, would legitimise and solidify a 'regime change'.

A key element of the American experiment in Iraq and Afghanistan was the construction of a 'human terrain system'. At its height, this system employed 27 teams of social scientists, specialists on Islam and Arabic or Pashto and Dari, to enter people's homes and map out Iraqi and Afghan social relations as participant-observers, creating a database that would 
chart the communities and ideologies of the population (Kelly et al. 2010). This system - what the geographer Derek Gregory (2008) referred to as 'armed social work' - was thought to produce a knowledge network that would anticipate insurgent threats. Ethnography aided in the targeted assaults necessary for the selective removal and internment of insurgent leaders in a network of camps. By 2008, Camp Bucca, the largest of these camps, had as many as 18,000 detainees-including Abu Bakr al-Baghdadi, the future leader of the Islamic State (Enders 2008).

Since 2016, a similar system has been put in place in Xinjiang (Mahmut 2019). Unlike in Afghanistan or Iraq, there is no organised, armed insurgency, yet Uyghurs and other Turkic Muslims have been targeted as 'pre-terrorists' in similar ways. Chinese authorities use many of the same 'enhanced interrogation' techniques used by the Bush administration. An important distinction, however, is that the Chinese Government pathologises nearly all forms of Turkic Islamic practice as expressions of mental illness, and strives to transform Muslims through psychiatric treatment, language education, political indoctrination, and coercive factory labour in an internment camp system much more extensive than the camps in Iraq or Afghanistan (Grose 2019). In Xinjiang, the police are not attempting to produce political regime change; the institutions of state are already fully within their grasp. Here there is something more. As in settler-colonial systems around the world (Wolfe 2006), they are attempting to produce deep epistemic and social elimination by detaining and retraining the entire population. This is accomplished through increasingly restrictive nested systems of biometric and digital surveillance checkpoints-ending in the tight constraints of the camps and prisons themselves. All Uyghurs and other Turkic Muslims are detained to varying degrees in what many describe as the 'open-air prisons' (sirttiki türme) of their communities.

\section{Adapting a Western framework}

State media and policing theorists in China noticed the shift in US militarism as early as 2007, when discussions of the 'Petraeus Doctrine' - the new counterinsurgency manual named for US General David Petraeussignalled a transformation of military science around the globe (Yang 2007). Over the next several years, scholars at elite police academies across China began to examine counterinsurgency theory-first, as practised 
by the US military and then, the way it was adapted and technologically assisted in Israel ( $\mathrm{Lu}$ and Cao 2014). In the space of less than a decade, this new theoretical paradigm was adapted in practice in Xinjiang.

Much of the impetus behind this shift from academic research to policy implementation emerged from the tragic events of 2013 and 2014 in Beijing and Kunming, respectively. In the first of the two incidents, a family of Uyghur attackers drove a vehicle into a crowd of tourists in Tiananmen Square on 28 October 2013; in the second, on 1 March 2014-an episode often referred to as 'China's 9/11' - Uyghur attackers killed dozens of Han travellers in the Kunming railway station (Doyon 2019). Within a year, the new forms of policing that had been observed in Palestine, Afghanistan, and Iraq coalesced into a series of Chinese National Science Foundation policing theory projects, such as 'The Anti-Terrorism Mode of Community Policing with Chinese Characteristics' (Lowe 2017).

One of the leaders of this new paradigm of Chinese policing, which stresses 'prevention' (预防) through 'preemptive strike' (先发制人), is a young scholar from Shenyang named Cao Xuefei. Named to the project while still a $\mathrm{PhD}$ student in police science and antiterrorism at Charles Sturt University in Australia, Cao and a colleague named Lu Peng published an influential article on the way Israeli counterinsurgency theory should be used as an inspiration for counterterrorism in Xinjiang. As his thinking continued to evolve, Cao and another colleague translated a book called Policing Terrorism by CVE expert David Lowe (2017). Their award-winning Chinese translation of the book provided an 'empirical basis' from which to expand Chinese antiterrorism activities in relation to the Islamic State, which many suspected was connected to the Uyghur attacks in Beijing and Kunming. Lowe's book, which analysed the methods used by Islamic State affiliates in Britain to 'radicalise and recruit people to their causes', also stressed 'critical' methods of gathering intelligence through surveillance and community informants.

In an article that was published in the summer of 2016, Chinese policing theorists Ji Yantao and Yin Wei (2016) began to describe the way this turn in policing could be adapted in a Chinese context by emphasising the need to move to prevention rather than 'passive reaction' (被动反应). Ji and Yin argued that this new form of policing should supplement the military-style 'intervention' (千预) and 'harsh punishment and suppression' (打击和严 格的惩罚) that had typified earlier 'Strike Hard' (严厉打击) campaigns in Xinjiang. Yet, although they were suggesting a broader approach, they were careful to note that terrorism in China was rooted in social causes 
such as 'education, religion, ethnicity, and economic factors' and was 'not directly proportionate to police presence' (Ji and Yin 2016: 144). As per the position of the Chinese Communist Party (CCP) - which resonated with that of CVE advocates around the world-they claimed that Uyghurs were terrorism-prone because of their social and cultural systems and failed to acknowledge the role of police brutality and colonisation. In any case, they argued for the key focus of antiterrorism activities to shift to 'preemptive strikes' facilitated by civilian intelligence workers. At the core of this mode was a term Ji and Yin repeated 58 times in the space of 12 pages: 'prevention' (预防).

From their perspective, prevention encompassed three interlinked domains: 'strike prevention' (打击性预防), 'controlled prevention' (控制性预防), and 'protective prevention' (保护性预防). Strike prevention refers to the 'real-time control of key high-risk populations' (Ji and Yin 2016: 150) such as people like Gulbahar-that is, 'returning' (回流) terrorism suspects. Uyghurs who had lived abroad in Muslim-majority environments with open access to information, especially those for whom there was evidence linking them to other suspects, needed to be 'preemptively attacked. Once the terrorism suspect is in custody, they are moved into 'controlled prevention'. In this domain, people for whom there are not enough clues or evidence of terrorist intent need to be 'controlled' (控 制) to reduce the possibility of them committing a crime and to eliminate the 'unfavourable' (不利) aspects of their behaviour and thinking. The third form, protective prevention, refers to the prevention of potential terrorism through comprehensive intelligence-gathering and intervention in the 'breeding and spreading' (滋生和蔓延) of terrorist thought among the general population.

In a striking departure from non-Chinese counterinsurgency, all this intelligence-gathering was to be run through a shequ (社区), a term that refers to a state-directed neighbourhood watch unit in urban areas, or through village-level neighbourhood brigades (大队) 一 the most grassroots forms of party-facilitated policing in China. In Xinjiang, a shequ is staffed by mostly Han CCP members and police, but also employs Uyghur auxiliary police and mostly Han volunteer informants mobilised in the fight against terrorism through a weekly intelligence report quota system. Although Chinese community policing echoes the rhetoric of Euro-American counterterrorism, Ji and Yin argued that 'the people' (人民) must be pressured to report on their neighbours to fill in the blind spots in the intelligence system. In practice, the way this community 
policing is accomplished is by watching the Muslim population for 75 signs of 'extremist' (极端主义) Islamic practice, ranging from mosque attendance and Quran study to use of the common greeting 'Assalamu alaikum' (Buckley 2018; Greer 2018).

Special attention is focused on unauthorised religious knowledge and practice, and relationships to other suspects (Hunerven 2019). Unlike non-Chinese counterinsurgencies, each state-run watch unit is supported by a People's Convenience Police Station, which conducts 'seamless' (无缝) surveillance of Muslims within their jurisdiction through video monitoring, digital media history searches, biometric tracking, and human surveillance at mandatory political activities (Zhang 2016).

At the time when Ji and Yin were writing their 2016 article, the 'reeducation camps' in Xinjiang had not yet been fully built and sweeping purges of Uyghur and Kazakh societies had not yet begun. Less than one year later, Gulbahar and 1.5 million other Turkic Muslims began to be pushed through these domains of 'prevention' and subjected to the accompanying forms of social elimination.

\section{The Xinjiang mode}

In November 2016, a new article appeared, written by Wang Ding and Shan Dan, who were theorists in a Xinjiang police academy. The authors argued that the mode of preventive policing proposed by other policing theorists needed to be adapted in an explicit 'Xinjiang mode' (新疆模式) that would not only transform religion, but also lead to a 'deep fusion' (深 度融合) of Turkic minorities into Chinese culture. They wrote that this new mode would combine the full-spectrum intelligence 'war mode' (战 争模式) used by the US Army with a 'criminal mode' (犯罪模式) aimed at eradicating the root of terrorism - that is, 'extremist' religious ideology. These two aspects of preventive policing would be brought together with a 'governance mode' (治理模式) focusing on 'achieving a normal social order' (把社会秩序恢复到常态).

But what exactly was the 'normal' social order that Wang and Shan had in mind? As they put it: 'In the contemporary era there is no future for a religion without "culture" (Wang and Shan 2016: 25). Therefore, they suggested, there must be an acceleration of 'the deep fusion' of Chinese culture in Xinjiang-a process they argued was in fact the 'most distinctive aspect of the Xinjiang mode' of counterterrorism. They suggested that these adaptive approaches to counterterrorism were necessary due 
to the context of Xinjiang. Because it was a frontier region that was not yet fully settled by Han people, the local population generally lacked market integration. The deeper issue though remained religion, which, as Wang and Shan put it, was a 'personality problem' (个性问题). They wrote that the only way to deal with this was to be resolute in preventing people from being 'brainwashed' (洗脑) by a religion that had 'no culture' (没有文化). The implication was that because Turkic Muslims dangerously lacked 'culture'-a term that referred explicitly to 'Chinese culture'-there must be an acceleration of 'the deep fusion' of Chinese culture in Xinjiang.

Since Islam was so deeply integrated in the Xinjiang way of life, Wang and Shan argued that Turkic Muslims would need to unlearn nearly every aspect of their lives. The only way this could really be accomplished was if the entire population of non-Muslims in the region was brought into the process. They argued that people who possessed Chinese culture needed to 'occupy the positions of public opinion, the positions of cultural and social media platforms' throughout Xinjiang society (Wang and Shan 2016: 26). In writing this, they implied that Uyghur cultural leaders needed to be replaced through the full implementation of settler colonialism. Only then would 'unstable factors' be 'nipped in the bud' (把各类不稳 定因素消灭在萌芽状态).

When Gulbahar Jelilova was lured back to Xinjiang as a suspected 'returning terrorist' in mid-2017, much of what these scholars had advocated had been operationalised. Like hundreds of thousands of others, Gulbahar was targeted with a 'strike prevention' arrest. From there, she moved into 'controlled prevention' until she was eventually released into 'protective prevention'. Although she was found to be guilty of nothing other than being Uyghur and Muslim, the Xinjiang mode of counterinsurgency radically upended her life.

\section{Communities as prisons}

Those with the least amount of social power suffer the most in counterinsurgent war. According to the independent researchers at the organisation Iraq Body Count, there have been nearly 200,000 documented civilian deaths in Iraq since 2003 (IBC 2019). In some periods of the war in Afghanistan, the US military and its allies killed more civilians than the Taliban (Zucchino 2019). The cascading effect of these deaths and the widespread fragmentation of social life that has been produced through surveillance and removal in these spaces have produced tremendous 
forms of violence as social networks are broken and families are separated. The pain of counterterrorism is carried by those who remain into future generations and across communities.

As Arun Kundnani and Ben Hayes (2018) have shown, in Europe and North America, Muslim communities have been asked to carry the brunt of the social violence that is tied to CVE programs. Families, mosques, employers, and teachers are tasked with assessing their friends, relatives, and students as 'pre-criminals'. As in China, in Britain, extremism is 'pictured as a virus' and, counter to empirical evidence, religious ideology is assumed to be the primary cause of violence (Kundnani and Hayes 2018). Instead of considering the role of structural violence, colonialism, and institutionalised Islamophobia, it is simply assumed that Muslimsespecially those who practise their faith in public-are potential terrorists.

Yet, despite all these similarities, it is important to note that in liberal societies civil rights and free speech can produce a hedge against the implementation of mass extrajudicial detention and death. This was not the case in Iraq and Afghanistan. And it is not the case in China. As a Xinjiang official put it recently, what is happening to Uyghurs is 'not about human rights violations. Uyghurs have no rights' (ITV 2019). This framing resonates with a common interpretation of human rights in China: human rights mean the right of the majority Han people to be free from terrorism (Liu 2019). This in turn means they have the right to be free from their fear of Turkic Muslims-the only population in the country that is placed in the terrorism slot.

The violence of the process that confronted Gulbahar Jelilova was significantly lessened by the relative privilege of her Kazakhstani citizenship. Without it, she would still be in some form of detention like hundreds of thousands of others. Racialised religious discrimination, intrusions of privacy, political censorship, disappearances, detention without due process, and lack of personal and collective autonomy are institutionalised in Xinjiang. For most Uyghurs and Kazakhs, there is no foreseeable end to their detention. Their communities themselves have become their prisons. 
This text is taken from Xinjiang Year Zero, edited by Darren Byler, Ivan Franceschini and Nicholas Loubere, published 2022, The Australian National University, Canberra, Australia. 